Cortes D, Crocione C, Darling J, de Gussem E, Derksen C, Dupuis-Girod S, Foy P, Geisthoff U, Gossage JR, Hammill A, Heimdal K, Henderson K, lyer VN, Kjeldsen AD, Komiyama M, Korenblatt K, McDonald J, McMahon J, McWilliams J, Meek ME, Mei-Zahav M, Olitsky S, Palmer S, Pantalone R, Piccirillo JF, Plahn B, Porteous MEM, Post MC, Radovanovic I, Rochon PJ, Rodriguez-Lopez J, Sabba C, Serra M, Shovlin C, Sprecher D, White AJ, Winship I, Zarrabeitia R. Second international guidelines for the diagnosis and management of hereditary hemorrhagic telangiectasia. Ann Intern Med 2020;173:989-1001.

3. Baysal M, Demir S, Ümit EG, Gurkan H, Bas V, Karaman Gülsaran S, Demirci U, Kirkizlar HO, Demir AM. Genetic diagnosis of hereditary hemorrhagic telangiectasia: four novel pathogenic variations in Turkish patients. Balkan Med J 2020;37:43-46.

4. Hoag JB, Terry P, Mitchell S, Reh D, Merlo CA. An epistaxis severity score for hereditary hemorrhagic telangiectasia. Laryngoscope 2010;120:838-843.

5. Bossler AD, Richards J, George C, Godmilow L, Ganguly A. Novel mutations in ENG and ACVRL1 identified in a series of 200 individuals undergoing clinical genetic testing for hereditary hemorrhagic telangiectasia (HHT): correlation of genotype with phenotype. Human Mutation 2006;27:667675.

6. Richards S, Aziz N, Bale S, Bick D, Das S, Gastier-Foster J, Grody WW, Hegde M, Lyon E, Spector E, Voelkerding K, Rehm HL; ACMG Laboratory Quality Assurance Committee. Standards and guidelines for the interpretation of sequence variants: a joint consensus recommendation of the American College of Medical Genetics and Genomics and the Association for Molecular Pathology. Genet Med 2015;17:405-424.

7. $\mathrm{Xu} B G$, Liang J, Jia $K F$, Han T. Liver cirrhosis in a patient with hepatic hereditary hemorrhagic telangiectasia and Budd-Chiari syndrome: a case report. BMC Gastroenterol 2020;20:169.

8. Tortora A, Riccioni ME, Gaetani E, Ojetti V, Holleran G, Gasbarrini A. RenduOsler-Weber disease: a gastroenterologist's perspective. Orphanet J Rare Dis 2019;14:130.

9. University of Utah. Hereditary Hemorrhagic Telangiectasia Mutation Database. Salt Lake City, University of Utah Department of Pathology, 2020. Available at http://www.arup.utah.edu/database/HHT.

\title{
Can Hematological Findings of COVID-19 in Pediatric Patients Guide Physicians Regarding Clinical Severity?
}

\author{
Pediatrik Hastalarda COVID-19 Hematolojik Bulguları Klinisyenlere Klinik Ciddiyet Açısından \\ Yol Gösterebilir mi?
}

\author{
(1) Kamile Ötiken Arıkan, (DS Şahika Şahinkaya, (1) Elif Böncüoğlu, (D) Elif Kıymet, (1) Ela Cem, (1) Aybüke Akaslan Kara, (D) Nuri Bayram, \\ (1) ilker Devrim
}

University of Health Sciences Turkey, Izmir Dr. Behçet Uz Children Hospital, Clinic of Pediatric Infectious Disease, Izmir, Turkey

\section{To the Editor,}

The coronavirus disease-19 (COVID-19) pandemic originated in December 2019 in the city of Wuhan, the capital of Hubei Province, China. The virus then spread to numerous other countries in Asia and by January 2020 infected patients were identified in Europe [1]. Children of all ages are susceptible to infection by severe acute respiratory syndrome-coronavirus-2, the causative agent. Most children have relatively mild clinical symptoms without fever or pneumonia $[2,3,4,5,6,7,8]$.

We conducted a retrospective study at the University of Health Sciences Turkey, İzmir Dr. Behçet Uz Children's Hospital between March 30 and October 31, 2020.

A total of 3878 pediatric patients were tested and 353 (9.1\%) of them were diagnosed with COVID-19. Of these 353 children, 184 (52.1\%) were male (52.1\%) (female/male: 0.91).
The median age of the patients was 9 years (range: 4 days to 17 years). Thirty-five (9.9\%) patients had underlying diseases, most commonly a neurological disease $(n=9)$. Regarding severity, 9 (2.5\%), 293 (83\%), 38 (10.8\%), and 13 (3.7\%) cases were diagnosed as asymptomatic, mild, moderate, and severe/critical, respectively. Neutropenia (47.9\%) was the most common abnormal parameter in complete blood counts, followed by lymphocytosis (22.4\%), lymphopenia (20.7\%), leukopenia (9.1\%), neutrophilia (6.5\%), and thrombocytopenia (3.4\%) (Table 1).

Neutropenia was statistically significantly more common in neonates (84.6\%). Lymphocytosis and neutrophilia were statistically significantly more common in infants (75.9\%, $p<0.001$ and $23.3 \%, p<0.001$, respectively). Lymphopenia and leukopenia were statistically significantly more common in patients $>11$ years old $(38.4 \%, p<0.001$ and $15.2 \%, p=0.025$, 


\begin{tabular}{|c|c|c|c|c|c|}
\hline & Asymptomatic & Mild & Moderate & Severe/Critical & p \\
\hline Hemoglobin $(\mathrm{g} / \mathrm{dL})^{*}$ & 13.5 (8.9-14.3) & $12.5(8.9-11.5)$ & $12.3(6.6-16)$ & $8.9(2.5-13.1)$ & 0.001 \\
\hline Leukocytosis* & $1(11.1)$ & $14(5.6)$ & $6(15)$ & $2(28.6)$ & 0.011 \\
\hline Leucopenia** & $2(22.2)$ & $24(9.5)$ & $6(15)$ & $0(0)$ & 0.79 \\
\hline Neutropenia** $^{* *}$ & 7 (77.8) & $138(54.8)$ & $22(55)$ & $2(28.6)$ & 0.174 \\
\hline $\operatorname{ALC}\left(\times 10^{3} / \mu \mathrm{L}\right)^{*}$ & $2.2(1.2-9.1)$ & $2.2(0.23-14.6)$ & $2.7(0.7-8.2)$ & $1.7(0.68-6)$ & 0.93 \\
\hline Lymphocytosis** & $4(44.4)$ & $61(24.3)$ & $12(30)$ & $2(28.6)$ & 0.90 \\
\hline Lymphopenia** & $2(22.2)$ & $56(22.3)$ & $12(30)$ & $3(42.9)$ & 0.13 \\
\hline Platelets $\left(\times 10^{3} / \mu \mathrm{L}\right)^{*}$ & 321 (128-547) & $263(52-595)$ & 258 (146-665) & $196(55-358)$ & 0.15 \\
\hline Lymphocyte-to-white blood cell ratio* & $0.48(0.22-0.73)$ & $0.39(0.03-0.92)$ & $0.37(0.16-0.70)$ & $0.22(0.09-0.61)$ & 0.27 \\
\hline RDW (\%)* & $12.3(12-13.1)$ & $12.9(11.2-13.2)$ & $12.9(11.6-19.5)$ & $14.9(13-19.6)$ & 0.005 \\
\hline MPV (fL)* & $9.5(8.5-11.5)$ & $9.8(8-13.6)$ & $9.7(8.2-11.7)$ & $10.7(8.7-12.8)$ & 0.15 \\
\hline PDW (\%)* & $9.3(8.5-14.9)$ & $10.6(7.3-22)$ & $10.5(8.1-14.8)$ & $13.6(7.6-16.8)$ & 0.26 \\
\hline Prothrombin time (seconds)* & $13.2(9.5-14.1)$ & $12.8(9.4-17.7)$ & $13(11-16.4)$ & $14.7(12.9-20.9)$ & 0.037 \\
\hline Increased PT** & $0(0)$ & $10(6.7)$ & $1(3.4)$ & 4 (33.3) & \\
\hline aPTT (seconds) & $29.6(24.3-35.8)$ & $31.9(17.9-61.10)$ & $31.2(21.5-39.1)$ & $31.3(23.7-46)$ & 0.91 \\
\hline Fibrinogen $(\mathrm{mg} / \mathrm{dL})^{*}$ & $224(189-409)$ & $260(136-967)$ & $273(100-510)$ & $374(98-510)$ & 0.26 \\
\hline
\end{tabular}

respectively). Patients older than 11 years of age were more often thrombocytopenic, but this finding was not statistically significant $(p=0.17)$.

The neutrophil-to-lymphocyte ratio (NLR) was higher in severe/critical cases compared to cases of asymptomatic, mild, and moderate severity [median NLR values in asymptomatic, mild, moderate, and severe cases were as follows: 0.84 (range: $0.2-3), 1.12$ (0.04-28), 1.32 (0.11-4.6), and 3.39 (0.23-10), respectively; $p=0.25]$.

The platelet-to-lymphocyte ratio statistically significantly increased as age increased.

Lymphocyte-to-white blood cell ratio statistically significantly decreased as age increased and it was lower in severe/critical cases compared to cases of asymptomatic, mild, and moderate severity. Red cell distribution width (RDW) statistically significantly increased in severe cases (median values in asymptomatic, mild, moderate, and severe cases were as follows: 12.3 [range: 12-13.1], 12.9 [11.2-13.2], 12.9 [11.6-19.5], and 14.9 [13-19.6], respectively; $p=0.005)$. Median serum ferritin and D-dimer were statistically significantly increased in severe cases. Increased serum D-dimer was found to increase the risk of disease severity 2.9-fold (95\% confidence interval: 0.13-0.85, $p=0.022$ ).

In our findings, the NLR ratio was higher in severe/critical cases compared to cases of asymptomatic, mild, and moderate severity. Qin et al. [6] reported an increase in NLR in patients with severe disease compared to those without [8]. In our findings, RDW levels were also significantly higher in severe cases. In adult studies, it was concluded that elevated RDW at the time of hospital admission and an increase in RDW during hospitalization were associated with increased mortality 
risk for patients with COVID-19, compatible with our results $[6,9,10]$.

We recommend that clinicians closely monitor leukocyte count, lymphocyte count, platelet count, serum D-dimer, serum ferritin, and RDW as markers for potential progression to critical illness.

Keywords: COVID-19, Hematological parameters, Clinical severity, Red cell distribution width, Lymphopenia

Anahtar Sözcükler: COVID-19, Hematolojik parametreler, Klinik şiddeti, Kırmızı küre dağıım aralığı

Informed Consent: Retrospective study.

\section{Authorship Contributions}

Concept: K.Ö.A., I.D.; Design: K.Ö.A., I.D., A.A.K., S..Ş., E.C., E.B., E.K.; Data Collection or Processing: K.Ö.A.; Analysis or Interpretation: K.Ö.A., N.B., I.D.; Literature Search: K.Ö.A.; Writing: K.Ö.A.

Conflict of Interest: No conflict of interest was declared by the authors.

Financial Disclosure: The authors declared that this study received no financial support.

\section{References}

1. Lu H, Stratton CW, Tang YW. Outbreak of pneumonia of unknown etiology in Wuhan, China: the mystery and the miracle. J Med Virol 2020;92:401402 .
2. Zhou MY, Xie XL, Peng YG, Wu MJ, Deng XZ, Wu Y, Xiong U, Shang LH. From SARS to COVID-19: what we have learned about children infected with COVID-19. Int J Infect Dis 2020;96:710-714.

3. Jiang L, Tang K, Levin M, Irfan O, Morris SK, Wilson K, Klein JD, Bhutta ZA. COVID-19 and multisystem inflammatory syndrome in children and adolescents. Lancet Infect Dis 2020;20:276-288.

4. Lippi G, Plebani M. The critical role of laboratory medicine during coronavirus disease 2019 (COVID-19) and other viral outbreaks. Clin Chem Lab Med 2020;58:1063-1069.

5. Henry BM, Lippi G, Plebani M. Laboratory abnormalities in children with novel coronavirus disease 2019. Clin Chem Lab Med 2020;58:1135-1138.

6. Sharma D, Dayama A, Banerjee S, Bhandhari S, Chatterjee A, Chatterjee D. To study the role of absolute lymphocyte count and RDW in COVID 19 patients and their association with appearance of symptoms and severity. J Assoc Physicians India 2020;68:39-42.

7. Qin C, Zhou L, Hu Z, Zhang S, Yang S, Tao Y, Xie C, Ma K, Shang K, Wang W, Tian DS. Dysregulation of immune response in patients with coronavirus 2019 (COVID-19) in Wuhan, China. Clin Infect Dis 2020;71:762-768.

8. Tang N, Li D, Wang X, Sun Z. Abnormal coagulation parameters are associated with poor prognosis in patients with novel coronavirus pneumonia. J Thromb Haemost 2020;18:844-847.

9. Wang $C$, Zhang $H$, Cao $X$, Deng $R, Y e ~ Y, F u ~ Z$, Gou L, Shao $F$, Li J, Fu W Zhang X, Ding X, Xiao J, Wu C, Li T, Qi H, Li C, Lu Z. Red cell distribution width (RDW): a prognostic indicator of severe COVID-19. Ann Transl Med 2020;8:1230.

10. Henry BM, Benoit JL, Benoit S, Pulvino C, Berger BA, Olivera MHS, Crutchfield CA, Lippi G. Red blood cell distribution width (RDW) predicts COVID-19 Severity: a prospective, observational study from the Cincinnati SARSCoV-2 Emergency Department Cohort. Diagnostics (Basel) 2020;10:618. 